\title{
Treatment of gonorrhoea with single injections of gentamicin
}

\author{
D. HANTSCHKE, P. STRAUSS, G. LINZENMEIER, D. GAHLEN, AND W. HELLER \\ From the Dermatological Clinic and Out-Patient Department, the ENT-Clinic and the Institute of Microbiology, \\ Ruhr-University, Bochum, Essen, Germany
}

Penicillin is still the antibiotic of choice in the therapy of gonorrhoea, but the administration of this antibiotic may be limited by various factors. Anaphylactic shock may occur and may even be fatal (Rosenthal, 1958; Fazekas and Veress, 1964; Schümmelfeder, Klein, and Stüttgen, 1965).

A higher incidence of such complications is to be expected as a result of the gradual increase in the number of those with penicillin allergy (Lückerath, 1969; Maciejowska, 1969; Sönnichsen, Metzner, and Rietschel, 1969). On the one hand detection of such persons is improved by more sensitive testing methods. On the other hand the general population is brought increasingly into contact with penicillin, either by penicillin-contaminated food or by infection with penicillin-producing dermatophytes (Götz, 1962; Blum and de Weck, 1966).

The increased number of gonococcal strains less sensitive to penicillin has been widely reported (Juhlin, 1965; Amies, 1967; Smith and Levey, 1967; Storck and Schwarz-Speck, 1969; Silver and Darling, 1971; Wols-van der Wielen, 1971). This has also been our experience in recent years, and is another reason why numerous other antibiotics and chemotherapeutic agents have been used to treat gonorrhoea. Hellgren (1969) thought that treating gonorrhoea with penicillin was no longer justified because the disease was not serious enough to warrant the risk of fatal anaphylaxis.

For these reasons, we have tried the relatively new antibiotic gentamicin, which has the additional advantage of leaving $T$. pallidum unaffected.

\section{Methods}

Smears and cultures were taken from the urethra in males and from the cervix, urethra, and sometimes the anal canal, in females. The methods of taking and staining the

Received for publication July 10, 1972

Address for correspondence: Dr. D. Hantschke, Dermatological Clinic, Ruhr University, 4300 Essen, Hufelandstrasse 55, West Germany smears and of setting up the cultures have been reported in detail elsewhere (Hantschke, 1970). Rapid cultural diagnosis was obtained by fluorescent antibody staining after 24 hrs' incubation. Strains of Neisseria gonorrhoeae were confirmed by fermentation reactions. Blood urea nitrogen and serum creatinine levels were determined. Full ENTexamination was undertaken, including audiometry and caloric tests. Only when all these investigations gave results within the normal range were the patients given gentamicin, as a single intramuscular injection in a dosage of $5 \mathrm{mg}$. per $\mathrm{kg}$. body weight.

\section{FOLLOW-UP TESTS}

Follow-up smears and cultures were taken on three, and in complicated infections, four occasions after treatment - the last between the 3rd and 10th day. The blood urea nitrogen and serum creatinine estimations were also repeated.

A further ENT examination was carried out in all cases on the 6th day after treatment and was repeated in many cases 4 weeks after treatment.

\section{Serum levels}

In five patients serum levels of gentamicin were estimated. Specimens were taken before therapy-as a control -and $30 \mathrm{~min} ., 1 \mathrm{hr}, 90 \mathrm{~min}$., and 2, 4, 8, 12, and $24 \mathrm{hrs}$ after the injection. The serum levels were determined by the well-diffusion method. To special plates containing $100 \mathrm{ml}$. DST-agar (Oxoid), $1 \mathrm{ml}$. sporular suspension (Bacillus subtilis ATCC 6633; germ count 15 million per $\mathrm{ml}$.) was added. Into a well of $9 \mathrm{~mm}$. diameter was placed $0.1 \mathrm{ml}$. of the pertinent serum dilution. The pre-treatment specimen of serum and a phosphate buffer standard served as controls. Pre-diffusion at room temperature for $2 \mathrm{hrs}$ was followed by aerobic cultivation for 20 to $24 \mathrm{hrs}$. The results thus yielded were related to the phosphate buffer standard.

\section{Results}

Altogether 62 patients with gonococcal infection (48 females and 14 males) were treated. Two women had salpingitis, and one man epididymitis. Cure was obtained in 58 cases ( 94 per cent.), but gonorrhoea recurred in three women and one man. 
Peak serum levels were reached 30 minutes after the injection, and usually started to fall after 2 hours. After 12 hours the level was hardly measurable (Figure). The levels obtained are well above the minimum inhibitory concentrations (MICs) of the strains of gonococci which we have tested.

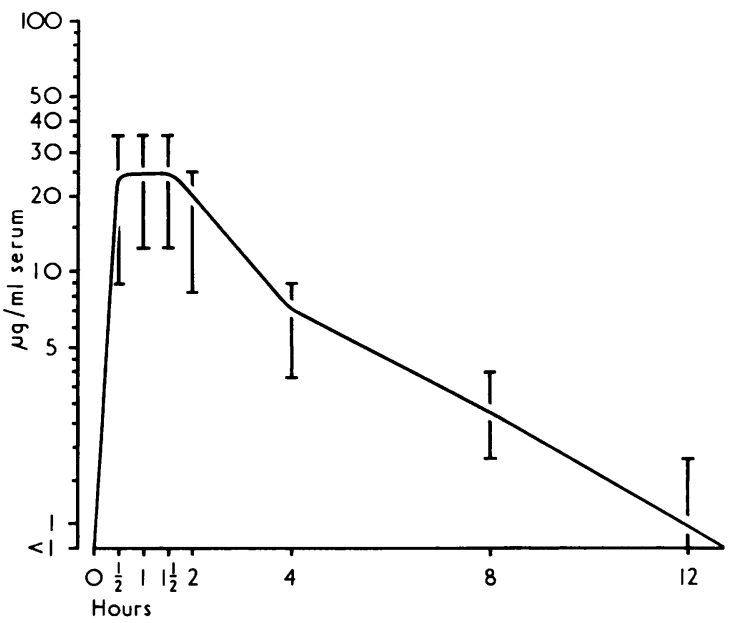

FIGURE Fall in mean serum levels within $24 \mathrm{hrs}$ after a single injection of gentamicin $5 \mathrm{mg}$. $/ \mathrm{kg}$. body weight

Blood urea nitrogen values remained within the normal range. In only two instances were serum creatinine values above normal, in one case before and in the other after therapy; later estimations yielded normal values in both.

The ENT examinations showed no evidence of ototoxicity in any of the thirty patients assessed; in some of these the assessment was made as long as 1 year after treatment.

\section{Discussion}

Reliable diagnostic methods are a prerequisite for the evaluation of a new antibiotic in the treatment of gonorrhoea. Methylene-blue and Gram-stained smears offer only presumptive evidence; accurate diagnosis requires biochemical tests or differentiation under the fluorescent microscope. We did not obtain satisfactory results by direct fluorescent antibody staining and prefer the 'delayed' method. Reyn (1969) and Petzoldt (1971) reported similar observations.

A single-injection treatment which has no sideeffects is particularly valuable in patients with gonorrhoea, especially if they are asymptomatic and have little incentive to seek treatment.

We arrived at a dosage of $5 \mathrm{mg}$. gentamicin per kg. body weight for two reasons:
(1) The MICs yielded by 158 strains of gonococci tested by the serial dilution test described by Hantschke (1970). With fourteen strains the MIC was 0.09 $\mu \mathrm{g} . / \mathrm{ml}$. and with five strains $6.25 \mu \mathrm{g} . / \mathrm{ml}$; the remaining strains showed intermediate values.

(2) The findings of other workers (Polemann and Eichler, 1967; Hantschke and Mauss, 1970; Felarca, Laqui, and Ibarra, 1970; Mirarchi and Plante, 1971). The last named used almost the same dosage as we did, whereas Felarca and others (1970) gave up to $6 \mathrm{mg}$. gentamicin per $\mathrm{kg}$. body weight. None of these authors observed any side-effects. The aminoglycoside antibiotics are known to cause vestibular and auditory damage. Such effects have been reported from the use of kanamycin (Jørgensen and Schmidt, 1962), neomycin (Wagemann, 1960), and also gentamicin (Pirsig and Rollin, 1969; Witzel, 1970; Federspil, 1971). A common denominator could be established with the majority of the patients so affected, namely a marked renal insufficiency.

From the experimental work of Voldrich (1965) and Stupp, Rauch, Sous, and Lagler (1966), the possibility of ototoxicity may be deduced as follows: when an aminoglycoside antibiotic is injected, high serum levels are promptly obtained with a half-life of 30 to 90 minutes. The antibiotic level in the perilymph of the inner ear does not rise at the same rate but excretion from this site is retarded. When therapy with an aminoglycoside antibiotic is continued for some time, even with relatively low doses, an accumulation may occur in the inner ear fluid, particularly in the presence of renal insufficiency. When a single high dose is given there may be a marked rise in the aminoglycoside antibiotic level in the perilymph of the inner ear. Stupp (1970) demonstrated this experimentally with kanamycin in the guinea-pig. If saturation of the perilymph occurs after either method of administration and is maintained over a given period (as yet unknown) toxic damage of the sensory cells probably occurs. None of our patients treated with gentamicin showed evidence of ototoxicity and those with slightly impaired hearing before treatment showed no deterioration on follow-up, but the serum levels obtained in our patients might not be safe in patients with renal insufficiency or in a poor general state of health.

Holzmann, Tupath-Barniske, and Morsches (1969) showed, in a serial dilution test, that concentrations of gentamicin of 0.0005 to $500 \mathrm{\mu g}$./ml. nutrient broth had no effect on Treponema pallidum. These observations are in contrast to those of Heitmann and Bill (1971), but are supported by the recent large-scale investigations of Petzoldt (1972). Gentamicin treatment of gonorrhoea does not mask concomitant syphilis. 


\section{Summary}

A single injection of $5 \mathrm{mg}$. gentamicin per $\mathrm{kg}$. body weight was used to treat 62 patients with gonorrhoea. Treatment was preceded and followed by ENT examinations and the determination of blood urea nitrogen and serum creatinine levels. The treatment was successful in 58 patients, giving a cure rate of 94 per cent. No side-effects were observed. Serum levels were measured in five cases and were well above the MIC values of 158 strains of Neisseria gonorrhoeae tested by us.

In spite of our good results and the absence of side-effects, gentamicin cannot yet be recommended as routine therapy for gonorrhoea as the number of cases treated was small, but its use is indicated in patients with penicillin allergy or suspected concomitant syphilis and in those who have failed to respond to other antibiotics, providing renal and auditory function are normal.

The assistance of Mr. G. Olschewski and Miss I. Osterhaus in the laboratory studies and of Miss E. Hennicke in the serum level determinations is acknowledged with appreciation. We also wish to thank Miss $M$. Klooss for her help in translating the paper.

Gentamicin was supplied as 'Sulmycin' ampoules by Byk-Essex, Münich, Germany.

\section{References}

Amies, C. R. (1967) Canad. med. Ass. F., 96, 33

BLUM, G., and DE WECK, A. L. (1966) Dermatologica (Basel), 133, 461

FAZERAS, I. G., and Veress, L. (1964) Z. ärztl. Fortbild., 58, 952

FEDERSPIL, P. (1971) H.N.O. (Berl.), 19, 328

FelarCa, A. B., LaQui, E. M., and IbarRa, L. M. (1970) 'Therapeutic dose response and tolerance studies on gentamicin in gonococcal urethritis'. Abstr. of paper presented at 63rd Annual Convention, Philippine Medical Association, Celen City, P.I., May 6 to 9, 1970

GöTZ, H. (1962) 'Die Pilzkrankheiten der Haut durch Dermatophyten', in 'Handbuch der Haut- und Geschlechtskrankheiten', ed. J. Jadassohn, Erganzungswerk, IV/3. Springer, Berlin

HANTsChKE, D. (1970) Z. Haut- u. Geschl.- Kr., 45, 49

- and Mauss, J. (1970) Ibid., 45, 407

HeitmanN, H. J., and Bill, S. (1971) Ibid., 46, 87

HellaRen, L. (1969) Personal report. Dermatological Clinic, University of Göteborg

Holzman, H., Tupath-Barniske, R., and Morsches, B. (1969) Hautarzt, 20, 404

JørGensen, M. B., and Schmidt, M. R. (1962) Acta oto-laryng. (Stockh.) 55, 537
JuHLin, I. (1965) Acta derm.-venereol. (Stockh.), 45, 223

LüCKeRATH, I. (1969) Rhein. Arrztebl., 23, 485

MaciejowsKa, E. (1969) Derm. Mschr., 155, 751

Mirarchi, P. S., and Plante, G. E. (1971) Sem. méd. (B. Aires), 138, 372

Petzoldt, D. (1971) 'Die Immunfluoreszenz in der Gonorrhoe-Diagnostik'. Congress of Dermatology, Berlin, October, 1971

- (1972) Hautarzt, 23, 402

Pirsig, W., and Rollin, H. (1969) H.N.O. (Berl.), 17, 274

PolemanN, G., and Eichler, D. (1967) 'Zur Wirkung des Antibiotikum Gentamycin bei der Gonorrhoe'. Kongressbericht; 5. Internationaler Chemotherapiekongress, Wien, 5, 231-234

ReYN, A. (1969) Bull. Wld Hlth Org., 40, 245

Rosenthal, A. (1958) f. Amer. med. Ass., 167, 1118

SCHÜMMELFEDER, N., KleIN, H. J., and StüTtGeN, G. (1965) Med. Welt (Stuttg.), 1, 693

Silver, P. S., and DarLING, W. M. (1971) Brit. F. vener. Dis., 47, 367

Smith, D., and Levey, J. (1967) Med. f. Aust., 1, 849

SõNNICHSEN, N., METZNER, H., and RIETSCHEL, L. (1969) Derm. Mschr., 155, 739

StoRCK, H., and SchWARZ-SPECK, M. (1969) Dermatologica (Basel), 139, 254

STUPP, H. F. (1970) Acta oto-laryng. (Stockh.), Suppl. 262

-, RAuCH, S., Sous, H., and LAGLeR, F. (1966) Ibid. 61, 435

VolDŘich, L. (1965) Ibid., 60, 243

WAGEMANN, W. (1960) H.N.O. (Berl.), 8, 146

WITZEL, L. (1970) Fortschr. Med., 88, 705

WOLs-vAN DER WIELEN, A. (1971) Brit. f. vener. Dis., 47, 190

Traitement de la gonococcie par une injection unique de gentamicine

\section{SOMMAIRE}

On a traité 62 malades gonococciques avec une seule injection de $5 \mathrm{mg}$. de gentamicine par kg. de poids. Le traitement a été précédé et suivi d'un examen ORL et par la recherche de l'azotémie et du niveau de la créatinine sérique. La guérison fut obtenue chez 58 malades, soit un taux de guérison de 94 pour cent. Il ne fut pas observé d'effets secondaires. Les taux sanguins furent mesurés dans 5 cas et étaient bien au dessus de la CMI de 158 souches de Neisseria gonorrhoeae testées par nous.

Malgré nos bons résultats et l'absence d'effets secondaires, la gentamicine ne peut être encore recommandée comme traitement de routine, mais son emploi est indiqué chez les malades allergiques à la pénicilline ou suspects d'une syphilis concomitante et chez ceux qui n'ont pas répondu aux autres antibiotiques; ceci à condition que leurs fonctions rénales et auditives soient normales. 